\title{
Occurrence and Virulence Characterization of Aeromonas hydrophila in Salad Vegetables from Punjab, India
}

\author{
Kamalpreet Kaur ${ }^{1 *}$, Param Pal Sahota ${ }^{1}$, Mandeep Singh Hunjan², \\ Bhavish Sood $^{1}$, Manmeet Kaur ${ }^{1}$ and Jaspreet Kaur ${ }^{1}$ \\ ${ }^{1}$ Department of Microbiology, ${ }^{2}$ Department of Plant Pathology, Punjab Agricultural University, \\ Ludhiana-141004, Punjba, India \\ *Corresponding author
}

\section{A B S T R A C T}

\begin{tabular}{|l|}
\hline Ke y w o r d s \\
Aeromonas \\
hydrophila, salad \\
Vegetable, \\
Epidemiological \\
surveillance, \\
Virulence. \\
\hline Article Info \\
\hline $\begin{array}{l}\text { Accepted: } \\
\text { 07 September } 2017 \\
\text { Available Online: } \\
\text { 10 November } 2017\end{array}$ \\
\hline
\end{tabular}

The consumption of fresh and minimally processed vegetables is considered healthy, outbreaks related to the contamination of these products are frequently reported. Present study aimed to evaluate the microbiological quality and the occurrence of A. hydrophila in external, internal and macerated part of salad vegetables (cucumber, radish, carrot, tomato, cabbage, long melon and spinach) from the fields of Punjab Agricultural University and local markets of Ludhiana. Epidemiological surveillance conducted showed the occurrence of A. hydrophila in $82.5 \%$ of total tested samples, cucumber (80\%), radish (83\%), cabbage $(100 \%)$, carrot $(74 \%)$, long melon $(85 \%)$, spinach $(100 \%)$ and tomato $(68.5 \%)$. Total plate count ranged from 4.82 to $6.25 \mathrm{log} \mathrm{cfu} / \mathrm{g}$. Aerobic plate count of A. hydrophila procured from field and local market ranged between 2.79-3.93 log cfu/g, A. hydrophila count from internal, external and macerated part was $2.54,3.06$ and $3.73 \mathrm{log} \mathrm{cfu} / \mathrm{g}$. Isolate were molecularly confirmed as A. hydrophila by $16 \mathrm{~s}$-rDNA specific primer. Virulence was confirmed by gene specific primers, act (232 bp) and ahh (130 bp). Results of the study showed that salad vegetables possess a potential risk for the consumers.

\section{Introduction}

Aeromonas hydrophila is quotidian waterborne microorganisms that is often enlaced as a causative agent of clinical infections and has been isolated from animal and plant based food products [1]. It is gram-negative, facultative anaerobe, non-spore forming, rodshaped motile, catalase, oxidase and positive. The genus is made up of psychrophiles and mesophiles. A. hydrophila is frequently known to cause human infections such as septicemia, gastroenteritis and cellulitis, wound sepsis with necrosis, gangrene, pneumonia and traveler's diarrhea resulting from improper handling and consumption of contaminated food [2]. Aeromonas presently is considered as food-borne pathogen of emerging importance and is not listed in the Contaminant Candidate List of food. It has gained attention for potential to grow at refrigeration temperature, association with salad vegetables, assistance of antibiotic resistance and the capability to persist safety treatments in food [3]. Virulence gene detection is important to determine the potential pathogenicity of Aeromonas [4] due to the involvement of pathogenic genes and extracellular proteins including enterotoxin, hemolysin, aerolysin, various hydrolytic 
enzymes [5]. Despite the nutritional and health benefits of fresh produce, gastroenteritis related outbreaks have increased in recent years [6]. Being sources of high energy and rich in minerals, vitamins, fibers, and phenolics, salad vegetables constitutes an important food group that is linked to maintenance and well-being of individuals and helps to reduce incidence of chronic diseases.

In the farm to table process, there are many sources of contamination of fresh vegetables due to contact with disease causing microorganisms that include on the farm sources and off the farm sources [7]. Enteric bacterial pathogens enters agricultural environment via animal feces. The substantiate routes of crop contamination from feces are water, soil, compost/ seeds. Water can come in direct contact with crops in two ways: the irrigation and the often overlooked, pesticide or fertilizer diluents. The pathogen sources include those animals with freedom to wander into fields. The pathogens associated with these feces can be mobilized during rain or aerosolized by high winds.

Once mobilized in water, these pathogens can flow into surface water commonly used for irrigation and pesticide and fertilizer diluents in some growing regions. Surface water can flow directly into field crops by flooding or percolate through the soil column into groundwater.

Fresh produce following cutting has more water activity and possess easily accessible nutrients on cut surfaces which than intact and supports the growth of food-borne pathogens by serving as the potential organic and inorganic substrates for microorganisms [8]. Preferential niches of plants for these bacteria include wounds, roots, trichomes, stomata and substomatal chamber.
The occurrence of antibiotic resistance in prevailing and pathogenic microbes in vegetables contributes to the horizontal proliferation of resistance within distinct isolates. The resistance gene on transferable elements assist dispersal of resistance and extensive utilization of antimicrobials enables direct or co-selection of resistance [9]. Consequently, the occurrence of antibiotic resistant Aeromonas in fresh produce develops a principal interest for the safety of consumers [10]. The objective of this study was to evaluate the prevalence $A$. hydrophila on salad vegetables.

\section{Materials and Methods}

\section{Sample collection}

A total of 205 sample of salad vegetable (cucumber, radish, carrot, cabbage, tomato, long melon and spinach) were collected from the local market, Ludhiana and vegetable farm Punjab Agricultural University (PAU), Ludhiana, Punjab for a period of one and a half year (2014-2016).

Vegetables from the farm were freed from coarse dirt, and samples from the market were randomly purchased at the vegetable counter. All vegetables were sold loose and unprocessed. Samples were individually packaged into plastic bags to avoid cross contamination and stored at $4^{\circ} \mathrm{C}$ until further processing within $48 \mathrm{~h}$. 95 sample of salad vegetables from the local market and 110 samples from PAU field was procured during the study (Table 1).

\section{Microbiological analyses}

Aerobic mesophilic count and documentation of A. hydrophila were quantified using classical methodologies, with the results being expressed as colony forming units $(\mathrm{CFU} / \mathrm{g})$. 
Enumeration of $A$. hyrophila was done from the external, internal and macerated part of the vegetable. Maceration of the whole vegetable sample was done using sterile scalpel blade. Compacted leaves of cabbage were used as internal and external part, spinach was used as a whole leaf in the study. Dilutions of the surface, internal and macerated portion of sample (25 grams) were enriched in Buffered Peptone water (BPW) $(225 \mathrm{ml})$ for 4 hours and suspension was plated in triplicate on Aeromonas Isolation HiVeg Medium Base using pour plating technique and incubated at $37^{\circ} \mathrm{C}$ for $24-48$ hours. Colonies were counted per dilution as $\log \mathrm{cfu} / \mathrm{g}$.

\section{Phenotypic characterization of $A$. hydrophila}

Gram's stain was used to examine the isolated bacteria for studying the microscopic properties as initial identification of A. hydrophila. Morphological colonies characteristics were recorded on the Aeromonas isolation HiVeg Medium Base for primary identification of A. hydrophila. Presumptively confirmed by biochemical tests; oxidase, catalase, Indole, Methyl- red, Voges- Proskauer test, motility, Arginine, Lysine, Gas from Glucose, sugar fermentation test, Urease, citrate, and $\mathrm{H}_{2} \mathrm{~S}$ production. Isolates were further confirmed for virulence by virulence based tests: Crystal violet $(\mathrm{CV})$ binding, Congo-Red binding test, Deoxyribonuclease (DNase) test, Protease production, Hemolysin production, Pyrazinamidase activity, Siderophore production and molecular method (Table 4).

\section{PCR detection of virulence genes}

Template DNA for PCR screening was prepared by processing $5 \mathrm{ml}$ of culture grown for $18 \mathrm{~h}$ at $30^{\circ} \mathrm{C}$, using an Easy DNA $®$ Isolation Kit (Invitrogen Inc.). The presence, concentration, and purity of total DNA in the prepared samples were detected by measuring the absorbance at 260 and $280 \mathrm{~nm}$ using TECAN 2000 Nanoquant Plate. PCR analyses were carried out to detect haemolysin gene (ahh) and AHCYTOEN gene (act). The PCR products and the ladder marker were resolved by electrophoresis on $0.8 \%$ agarose gel.

\section{Conditions for PCR amplification}

Polymerase Chain Reaction Polymerase chain reaction was used to detect 685 bp 16sRNA gene in isolates for confirmation of A. hydrophila. Primers specific for act gene: (232 bp product) and ahh: (130 bp) were used as the target genes for PCR amplification. A $30 \mu \mathrm{PCR}$ mixture contained $1.5 \mathrm{mM}$ of 25mM $\mathrm{MgCl}_{2}, 1 \mathrm{X}$ Go Taq TM buffer, 10 nmole each $200 \mu \mathrm{M}$ dNTPs, $0.2 \mathrm{mM}$ of dNTPs (Promega Inc.), $0.5 \mu \mathrm{M}$ of each primers, 2U of GoTaqTM DNA polymerase and $25 \mathrm{ng} / \mu \mathrm{l}$ of the DNA template.

The PCR was run under the following conditions: denaturation at $94^{\circ} \mathrm{C}$ for $5 \mathrm{~min}$ followed by $94^{\circ} \mathrm{C}$ for $30 \mathrm{sec}$, primer annealing at $57.5^{\circ} \mathrm{C}$ for $30 \mathrm{sec}$ (for act gene) $50^{\circ} \mathrm{C}$ for 40 sec (for ahh gene), extension for $40 \mathrm{sec}$ at $72^{\circ} \mathrm{C}$ and $7 \mathrm{~min}$ final extension at $72^{\circ} \mathrm{C}$. Amplicons were examined and visualized by electrophoresis in $0.8 \%$ agarose gel in TBE buffer. The gel was stained with EtBr (Sigma) and viewed in Gel Doc System.

\section{Results and Discussion}

\section{Detection of $A$. hydrophila}

A. hydrophila was detected in 169 from 206 (82.5\%) samples collected during the year 2014-2016. Altogether 25 isolates were obtained for further testing. Salad vegetables viz., carrot, cucumber, radish, tomato, long melon, spinach and cabbage showed significant difference $(p<0.05)$ in the mean 
count $(\log \mathrm{cfu} / \mathrm{g})$ of $A$. hydrophila. Mean count in cucumber was $3.17 \mathrm{log} \mathrm{cfu} / \mathrm{g}, 3.20$ $\log \mathrm{cfu} / \mathrm{g}$ in radish, $3.51 \log \mathrm{cfu} / \mathrm{g}$ in carrot, $3.41 \mathrm{log} \mathrm{cfu} / \mathrm{g}$ in tomato, $3.19 \mathrm{log} \mathrm{cfu} / \mathrm{g}$ in spinach, $4.02 \mathrm{log} \mathrm{cfu} / \mathrm{g}$ in cabbage and 3.55 $\log \mathrm{cfu} / \mathrm{g}$ in long melon.

Total plate count of vegetables was found to be $5.42 \mathrm{log} \mathrm{cfu} / \mathrm{g}$ in cucumber, $5.34 \mathrm{log} \mathrm{cfu} / \mathrm{g}$ in radish, $5.68 \mathrm{log} \mathrm{cfu} / \mathrm{g}$ in carrot, $5.79 \mathrm{log}$ $\mathrm{cfu} / \mathrm{g}$ in tomato, $6.25 \mathrm{log} \mathrm{cfu} / \mathrm{g}$ in spinach, 5.2 $\log \mathrm{cfu} / \mathrm{g}$ in cabbage and $5.77 \log \mathrm{cfu} / \mathrm{g}$ in long melon. It was found that $169 / 206$ (82.5\%) sample comprising of 20/25 (80\%) of cucumber, 25/30 (83\%) of radish, 20/28 $(100 \%)$ of cabbage, $26 / 35$ (74\%) of carrot, $34 / 40(85 \%)$ of long melon, $20 / 20(100 \%)$ of spinach and $24 / 35(68.5 \%)$ of tomato were bacteriologically contaminated (Table 2 ).

Aerobic mesophilic count from vegetables collected from vegetable farm PAU and local market Ludhiana ranged from a geometric mean of 4.82 to $6.25 \mathrm{log} \mathrm{cfu} / \mathrm{g}$ (Fig. 1). Mean count in cucumber from market and field was 5.42 and $6 \log \mathrm{cfu} / \mathrm{g}, 5.34$ and $5.46 \mathrm{log} \mathrm{cfu} / \mathrm{g}$ in radish, 5.68 and $5.8 \mathrm{log} \mathrm{cfu} / \mathrm{g}$ in carrot, 5.79 and $5.56 \mathrm{log} \mathrm{cfu} / \mathrm{g}$ in tomato, 6.25 and $5.23 \mathrm{log} \mathrm{cfu} / \mathrm{g}$ in spinach, 5.2 and $5.26 \mathrm{log}$ $\mathrm{cfu} / \mathrm{g}$ in cabbage and 5.77 and $4.82 \mathrm{log} \mathrm{cfu} / \mathrm{g}$ in long melon.

The highest level of contamination was observed in spinach from the market samples with the mean count of $6.25 \mathrm{log} \mathrm{cfu} / \mathrm{g}$ followed by cucumber with the count of $6 \mathrm{log}$ $\mathrm{cfu} / \mathrm{g}$ from field samples and least was observed in the long melon with mean count $4.82 \log \mathrm{cfu} / \mathrm{g}$ from field sample.

Results of [11] showed mean total plate count of ready to eat salad to be $6.7 \log \mathrm{cfu} / \mathrm{g}$.

Contamination of fresh produce by human pathogens can occur at the pre and postharvest stage. Pre-harvest application of raw or insufficiently composted animal faeces or sewage as fertilizer, irrigation with contaminated water is possible vehicles for the spread of human pathogens [12]. Postharvest practices include washing off the vegetables with contaminated water with fecal coliforms, improper packaging, transportation, contamination by food handlers during display. The agricultural practices and hygienic conditions used during harvesting, processing, packaging, transport, and storage in influence the initial microbial population [13].

High level of contamination in cucumber could be due to direct contact of fruit with soil or due to irrigation of crop with contaminated water. Vegetables that are often in contact with soil, insects, and animals during growing and harvesting in the field are more prone to be contamination by bacteria [14].

Cabbage and carrot being having good $\mathrm{pH}$ range of 4.9- 6.0, provides very favorable environment for the growth and proliferation of microorganisms. Additional factors like contaminated water, cross contamination, poor handling after harvest increments the survival of bacteria on it. Radish and long melon grows in the close proximity of soil from where it can harbor pathogenic bacteria, their water activity and $\mathrm{pH}$ ensures the bacterial survival on them.

The high load of contamination in leafy vegetables is due to surfaces exposure to contaminated environment, extensive utilization of untreated manure and more handling steps during post-harvest. The heavy load in spinach can be accounted to poor water conditions used for washing vegetables and sanitation conditions resulting in higher incidence of food and water borne diseases causing epidemics which then severely threatens the physical well-being of urban population. Pathogens on surface of produce 
can contaminate the inner surface during cutting and multiply if held at room temperature [15] due to high humidity, suitable $\mathrm{pH}$, temperatures and nutrients. Saddik et al., (198h5) [16] documented the aerobic count of salads which was more than $10^{6} \mathrm{cfu} / \mathrm{g}$ as vegetables get contaminated with pathogenic microorganisms in fields or amid harvesting, post-harvesting handling, preparing and dissemination.

In study conducted by McMohan et al., (2001) [17], 34\% of organic vegetables tested in study was contaminated with Aeromonas spp. Callister and Agger (1987) [18] detected $A$. hydrophila on vegetables and inferred that vegetable produce from retail could be an important source of A. hydrophila gastroenteritis. Saad et al., (1995) [19] reported occurrence of Aeromonas in $47.8 \%$ of vegetables. It has also been detected in lettuce from restaurant [20], pre-made salads [21] and commercial vegetable salads [22].

Minimally processed vegetables have a physical structure which is susceptible to microbiological invasion. So, both microbiological and physiological activities could play a role in quality degradation during storage. Besides the direct effect of microbiological activity on flavor quality, interaction with physiological and microbiological mechanisms during storage of commodities susceptible to microbiological invasion can occur [23].

Enumeration of $A$. hydrophila from local market and vegetable farm of PAU, Ludhiana

A. hydrophila detected from the local market, Ludhiana and PAU field showed the significant difference $(\mathrm{p}<0.05)$ in the mean $\log \mathrm{cfu} / \mathrm{g}$ count. The mean value of $A$. hydrophila isolated from local market samples (3.93 log cfu/g) was significantly higher by $24.4 \%$ than salad vegetable samples collected from PAU field (2.78 $\log \mathrm{cfu} / \mathrm{g})$ (Fig. 1). In a study conducted by [7] from retail shops in Italy showed 100 percent prevalence of $A$. hydrophila in chicory, mix salad and carrot.

Intense use of contaminated water for washing, the collapse of a biological structure due to poor handling, cut surfaces or abrasions, poor facilities and conditions for transportation and storage with the high risk of contamination can introduce pathogens directly to the produce at the market place.

Post-harvesting practices can damage the surfaces of leafy greens. Injured lettuce and spinach have been shown to provide favourable conditions for the growth and dissemination of E. coli O157:H7 and $S$. enterica.

The fecal-oral route of transmission of pathogens broadens to include workers handling of fruits and vegetables from the point of removal from the plant throughout all further stages of handling, including preparation at the retail and food service levels.

The possible reason for lower contamination in field samples can be attributed to the less exposed to flies, insects, animals, prudent use of fully composted farm yard manure, safe irrigation water and hygienic practices.

Ibenyassine et al., (2006) [24] reported the contaminated irrigation water and surface runoff water as a major source of contaminant in fields. River water contaminated with human and animal waste poses a serious health risk [25]. A food-borne outbreak of $A$. hydrophila in a college of Xingyi City, Guizhou, China, was reported in 2012 which was caused by salad ingredients washed in contaminated tank water [26]. 
Table.1 Sample collection

\begin{tabular}{|l|l|l|l|}
\hline \multirow{2}{*}{ Salad Vegetable } & \multicolumn{2}{l|}{ Collection site } & \multirow{2}{*}{ Total number } \\
\cline { 2 - 3 } & Local Market & PAU field & \\
\hline Cucumber & 10 & 15 & 25 \\
Radish & 15 & 15 & 30 \\
Carrot & 15 & 20 & 35 \\
\hline Cabbage & 10 & 10 & 20 \\
\hline Spinach & 10 & 10 & 20 \\
\hline Long Melon & 20 & 20 & 40 \\
\hline Tomato & 15 & 20 & 35 \\
\hline
\end{tabular}

Table.2 Primers used for targeting species specific virulent genes of A. hydrophila

\begin{tabular}{|c|c|c|c|}
\hline Gene & Primer & Sequence $\left(5^{\prime} \rightarrow 3^{\prime}\right)$ & Amplicon size(bp) \\
\hline $16 \mathrm{~s}$ & $\mathrm{~F}$ & GAAAGGTTGATGCCTAATACGTA & 685 \\
\hline 105 & $\mathrm{R}$ & CGTGCTGGCAACAAAGGACAG & 085 \\
\hline act & $F$ & AGAAGGTGACCACCAAGAACA & 232 \\
\hline & $R$ & AACTGACATCGGCCTTGAACTC & \\
\hline ahh & $\begin{array}{l}\mathrm{F} \\
\mathrm{R}\end{array}$ & $\begin{array}{c}\text { GCCGAGCGCCCAGAAGGTGAGTT } \\
\text { GAGCGGCTGGATGCGGTTGT }\end{array}$ & 130 \\
\hline
\end{tabular}

Table.3 Percentage contamination in salad vegetables

\begin{tabular}{|c|c|c|c|c|}
\hline \multirow[t]{3}{*}{ Vegetables } & \multirow{2}{*}{\multicolumn{2}{|c|}{$\begin{array}{c}\begin{array}{c}\text { Bacteriologically } \\
\text { Unsafe }\end{array} \\
\text { Location } \\
\end{array}$}} & \multirow{3}{*}{$\begin{array}{l}\text { Total number } \\
\text { of unsafe } \\
\text { sample }\end{array}$} & \multirow{3}{*}{$\begin{array}{c}\text { Total } \\
\text { percentage } \\
(\%) \\
\text { contamination }\end{array}$} \\
\hline & & & & \\
\hline & Market & Field & & \\
\hline Cucumber & $12 / 15$ & $8 / 10$ & $20 / 25$ & 80 \\
\hline Radish & $14 / 15$ & $11 / 15$ & $25 / 30$ & 83 \\
\hline Carrot & $15 / 20$ & $10 / 15$ & $26 / 35$ & 74 \\
\hline Cabbage & $10 / 10$ & $10 / 10$ & $20 / 20$ & 100 \\
\hline Spinach & $10 / 10$ & $10 / 10$ & $20 / 20$ & 100 \\
\hline Long Melon & $19 / 20$ & $15 / 20$ & $34 / 40$ & 85 \\
\hline Tomato & $15 / 20$ & $9 / 15$ & $24 / 35$ & 68.5 \\
\hline Bacteriologically Unsafe & $95 / 110$ & $73 / 95$ & $169 / 205$ & - \\
\hline Percent contamination & 86.3 & 76.8 & & \\
\hline
\end{tabular}


Table.4 Biochemical characteristics of A. hydrophila (\%)

\begin{tabular}{|c|c|}
\hline Galactose & 66 \\
\hline Xylose & 100 \\
\hline Fructose & 100 \\
\hline Arabinose & 83 \\
\hline Sucrose & 83 \\
\hline Dextrose & 100 \\
\hline Cellobiose & 66 \\
\hline Lactose & 33 \\
\hline Maltose & 100 \\
\hline Mannitol & 83 \\
\hline Methyl Red (MR) test & 100 \\
\hline Voges-Proskauer's (VP) test & 96 \\
\hline Oxidase test & 98 \\
\hline Catalase test & 100 \\
\hline Indole test & 100 \\
\hline Citrate utilization & 94 \\
\hline Triple Sugar Iron(TSI) test & 92 \\
\hline Esculin hydrolysis & 100 \\
\hline Phenylalanine deaminase agar test & 100 \\
\hline Urease test & 0 \\
\hline Nitrate test & 61 \\
\hline Lysine decarboxylase & 100 \\
\hline Ornithine decarboxylase & 0 \\
\hline Arginine dihydrolase & 100 \\
\hline Gelatinase production & 100 \\
\hline
\end{tabular}


Fig.1 Enumeration of $A$. hydrophila from local market and vegetable farm of PAU, Ludhiana

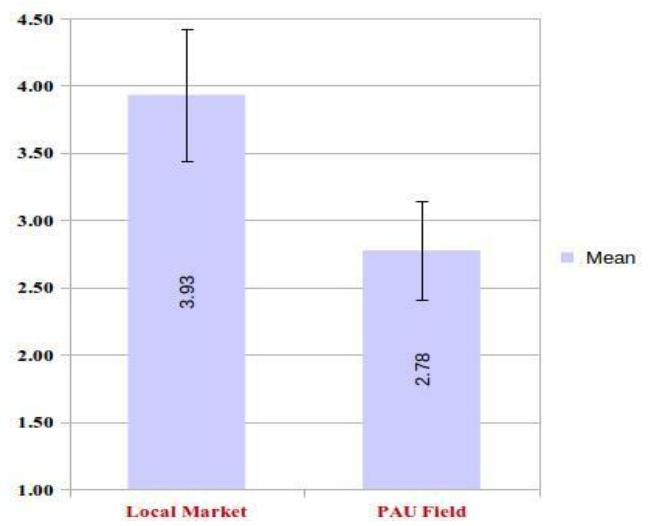

Fig.2 Enumeration of A. hydrophila from external, internal and macerated portion of salad vegetables

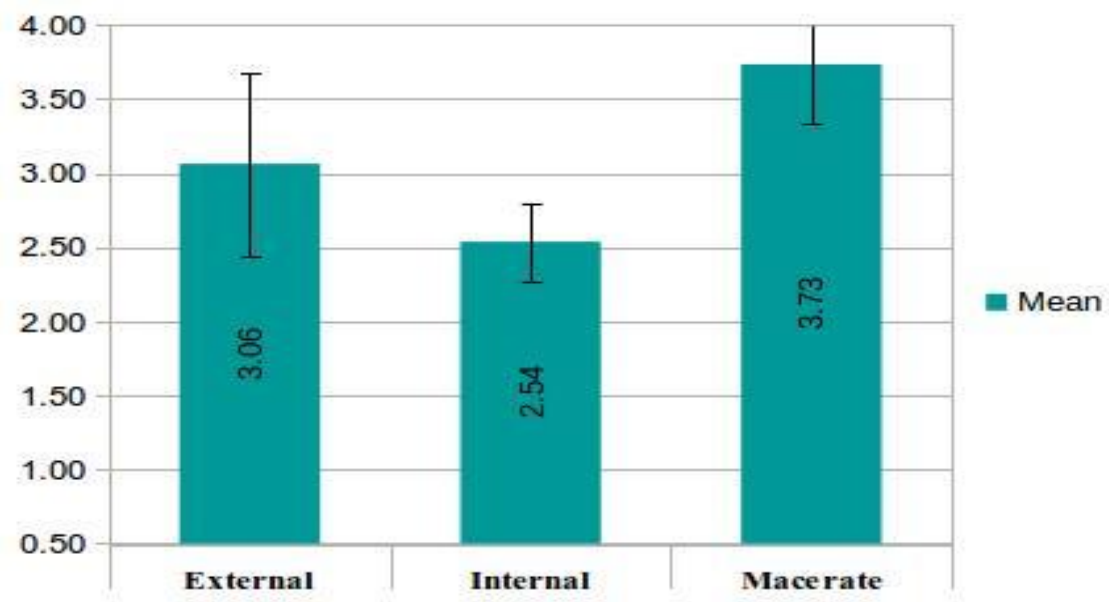

Fig.3 Comparative mean count of $A$. hydrophila in vegetable and vegetable part

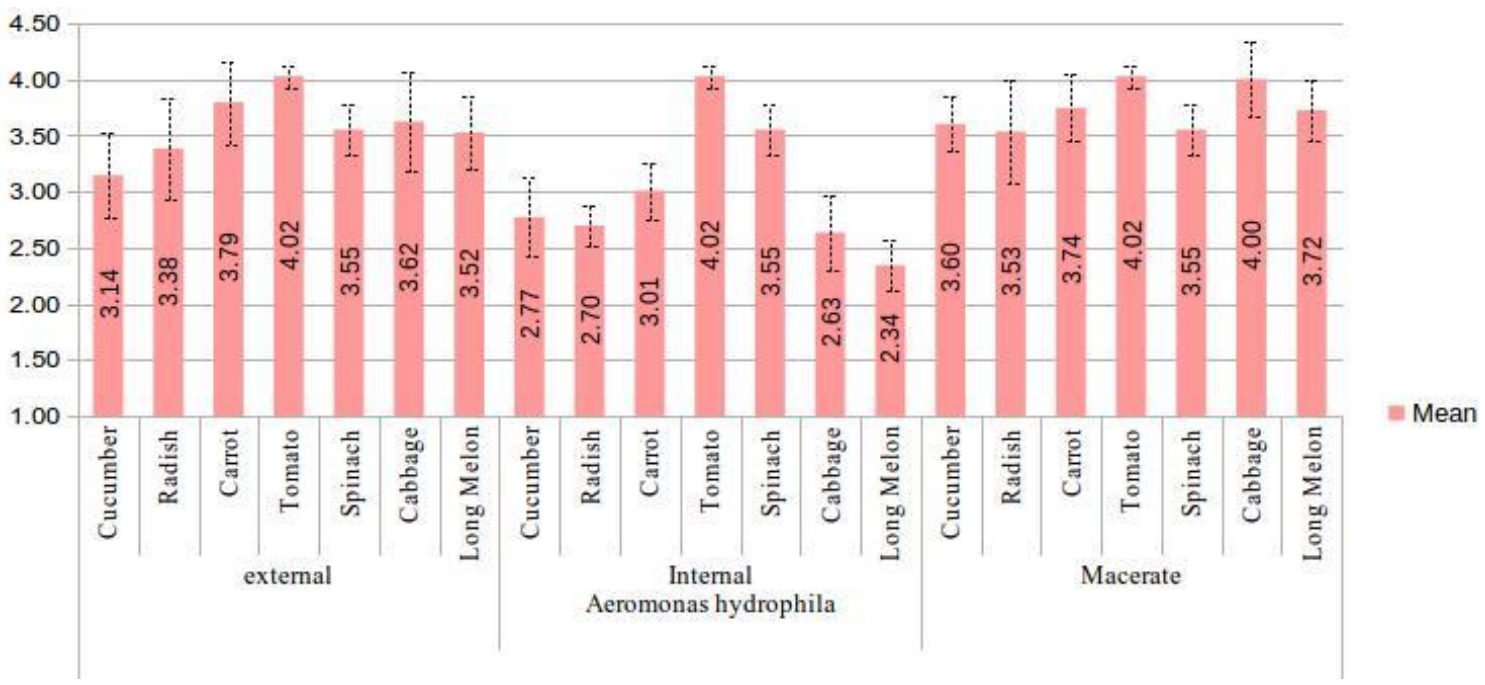


Fig.4 Comparative mean count of A. hydrophila with source of isolation and vegetable

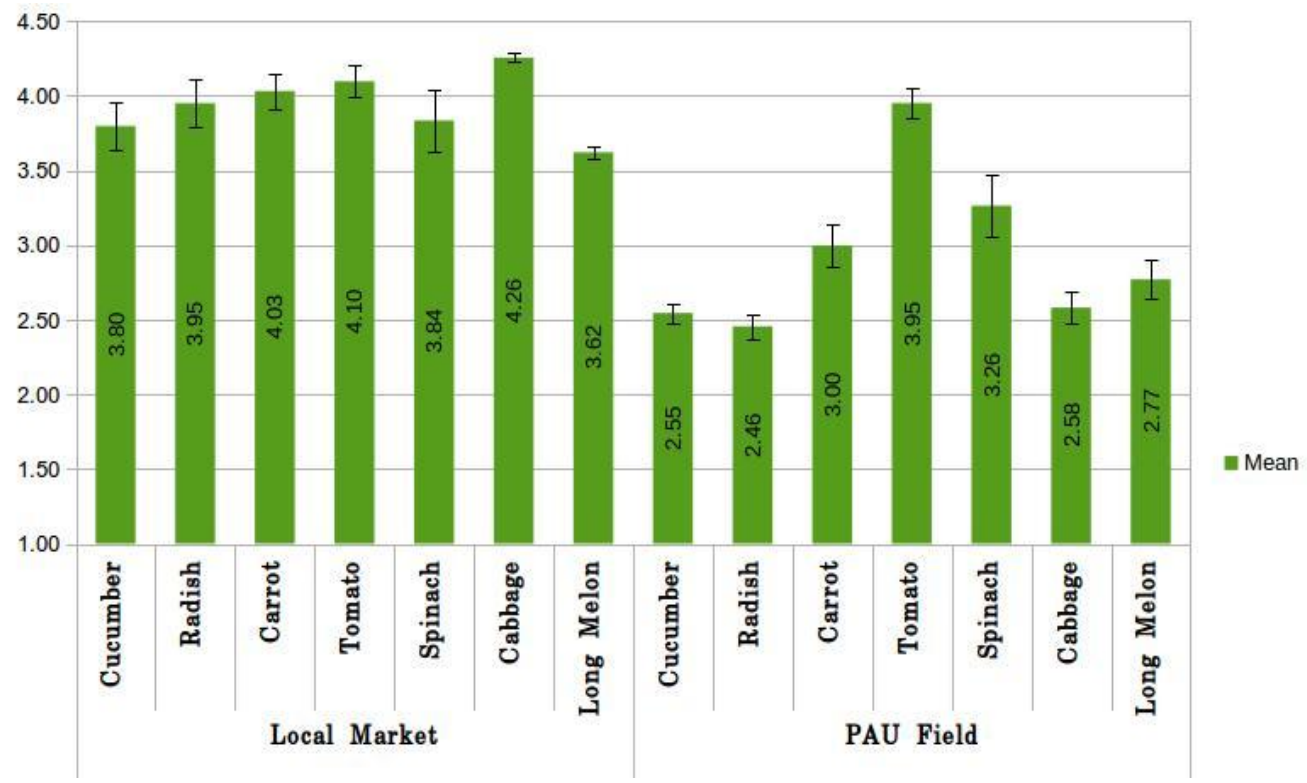

Enumeration of $A$. hydrophila from external, internal and macerated portion of salad vegetables

The internal tissue of leafy foods are generally considered as aseptic [27] but bacteria could be present there in low number but by up-taking the contaminated water through irrigation and washing processes, bacteria can be introduced [28]. A. hydrophila was isolated from internal, external and macerated part of salad vegetables and it showed the significant difference $(\mathrm{p}<0.05)$. The mean value $(\log \mathrm{cfu} / \mathrm{g})$ for macerated portion was significantly higher (3.73 log $\mathrm{cfu} / \mathrm{g}$ ) than the external portion (3.06 log $\mathrm{cfu} / \mathrm{g})$ followed by the internal portion (2.54 $\log \mathrm{cfu} / \mathrm{g}$ ) of the vegetables (Fig. 2).

The presence of pathogens in the internal parts of fresh produce is generally linked to the irrigation water used, contaminated soil could pose a serious risk factor to users because internalised pathogens are ineffective by normal washing with disinfectants. Donkor et al., (2010) [29] assessed the internalisation of microorganism in vegetables using standard microbiological methods, and the overall mean count was found to be $3.9 \times 10^{3}$ $\mathrm{cfu} / \mathrm{g} ; 8.3 \times 10^{2} \mathrm{cfu} / \mathrm{g} ; 2.1 \times 10^{2} \mathrm{cfu} / \mathrm{g} ; 3.4 \times 10^{2}$ $\mathrm{cfu} / \mathrm{g}$ for total plate count, coliform, faecal coliform counts and yeast counts respectively.

Comparative mean count of $A$. hydrophila in vegetable and vegetable part

The present study showed a significant difference $(\mathrm{p}<0.05)$ in the presence of $A$. hydrophila between the salad vegetable (cucumber, radish, carrot, tomato, spinach, cabbage and long melon) and the portion of salad vegetable (external, internal and macerated). According to results, the mean value $(\log \mathrm{cfu} / \mathrm{g})$ is highest $4.02 \mathrm{log} \mathrm{cfu} / \mathrm{g}$ in macerated portion of cabbage and in internal and external parts of tomato. The mean $\log$ cfu/g in external part for all vegetable parts ranges from $3.14 \log \mathrm{cfu} / \mathrm{g}$ to $4.02 \mathrm{log} \mathrm{cfu} / \mathrm{g}$, in internal part it ranges from $2.77 \mathrm{log} \mathrm{cfu} / \mathrm{g}$ to $4.02 \log \mathrm{cfu} / \mathrm{g}$ and in macerated part it ranged from $3.53 \log \mathrm{cfu} / \mathrm{g}$ to $4.02 \mathrm{log} \mathrm{cfu} / \mathrm{g}$.

Overall, macerated portion of all vegetable showed more percent of A. hydrophila 
contamination by $16.3 \%$ followed by external $(8.8 \%)$ and then internal part (6.6\%) (Fig. 3).

A. hydrophila could have contaminated tomatoes and cabbage due to the poor quality of water used in irrigation and washing purposes. The agricultural practices and hygienic conditions used during harvesting, processing, packaging, transport, and storage influences the initial microbial population [30]. Fruits and vegetables are cleaned, cooled, and conveyed in water and are treated with aqueous formulations of chemicals after harvesting to remove foreign matter and microorganisms [31]. The degree to which washing reduces the microbial load depends on the produce and the procedure used. Recycling of the wash water, a common practice in washing and hydrocooling, can lead to cross- contamination [32]. Microorganisms in the water may contaminate fruit through lenticels [33], stomata, and injuries incurred during harvesting [34]. Warmed tomatoes immersed in cool water containing bacteria were found to absorb water and bacteria. When the tomatoes immersed in water were at the same temperature as the water, they did not absorb water, but their surfaces were contaminated with bacteria [35].

Cabbage and carrot being having good $\mathrm{pH}$ range of 4.9- 6.0, provides a very favorable environment for the growth and proliferation of microorganisms. Additional factors like contaminated water, cross contamination, poor handling after harvest increments the survival of bacteria on it. Radish and long melon grow in the close proximity of soil from where it can harbor pathogenic bacteria, their water activity and $\mathrm{pH}$ ensures the bacterial survival on them.

The frequent utilization of polluted irrigation water, market handling and provision for sanitary standards (water for crop irrigation and washing) is lacking. Faecal coliform in irrigation water ranged between $498 \times 10^{3}$ and $2.7 \times 10^{6} 100 \mathrm{ml}^{-1}$ [36] which are exceeding the WHO recommended level of $1 \times 10^{3} 100$ $\mathrm{ml}^{-1}$ for unrestricted irrigation assessment of personal hygiene in food vendors.

\section{Comparative mean count of $A$. hydrophila with source of isolation and vegetable}

Present investigation yields significant difference $(\mathrm{p}<0.05)$ in the presence of $A$. hydrophila in salad vegetable (cucumber, radish, carrot, tomato, spinach, cabbage and long melon) with respect to the source of sample collection (local market and PAU, field).

Cabbage collected from local market showed the highest mean count of $4.26 \mathrm{log} \mathrm{cfu} / \mathrm{g}$ followed by tomato $4.10 \mathrm{log} \mathrm{cfu} / \mathrm{g}$, carrot, radish, cucumber (4.10 and $4.08 \mathrm{log} \mathrm{cfu} / \mathrm{g}$ ) from the same source. From field highest mean $\log \mathrm{cfu} / \mathrm{g}$ was observed in tomato 3.95 $\log \mathrm{cfu} / \mathrm{g}$ followed by spinach (3.26 log $\mathrm{cfu} / \mathrm{g})$, carrot (3.00 log $\mathrm{cfu} / \mathrm{g})$, long melon (2.77 log cfu/g), cabbage (2.58 log cfu/g), cucumber (2.55 log $\mathrm{cfu} / \mathrm{g})$ and radish $(2.46$ $\log \mathrm{cfu} / \mathrm{g})$.

Briefly, salad vegetables collected from the local market had 22.3 percent high contamination level of Aeromonas hydrophila than salad vegetables collected from the PAU field (Fig. 4).

Vegetables contaminated with pathogenic microorganisms are capable of causing human diseases while still on the plant in the farm, or during harvesting, transport, processing, distribution and marketing, or in the home [37]. Cabbage, tomato, carrot and radish samples procured from local markets and retail stores were found to have higher $\log _{10}$ $\mathrm{cfu} / \mathrm{ml}$ value in comparison to samples procured from university field. It has been 
suggested that a favourable environment allows pathogenic bacteria grow to detectable levels in these vegetables [38].

The issue of fresh produce spoilage is of high importance in the efforts to combat hunger, raise income and improve food security. Food spoilage by bacteria has an impact on food security for poor people, on food quality, safety and on the economic development. Roughly one-third of food produced for human consumption is lost or wasted globally, which amounts to about 1.3 billion tonnes per year [39]. Food losses take place at production, post-harvest and processing stages in the food supply chain [40].

The causes of food spoilage in low-income countries like India are mainly connected to financial, managerial and technical limitations in harvesting techniques, storage and cooling facilities in difficult climatic conditions, infrastructure, packaging and marketing systems. Given that many small holder farmers in developing countries live on the margins of food insecurity, a reduction in food losses could have an immediate and significant impact on their livelihoods.

\section{Phenotypic characterization}

The colonies of A. hydrophila were light brown colored colonies on HiVeg media base, with diameter ranged from (2-3) $\mathrm{mm}$. A. hydrophila, a gram negative bacillus, straight shape, singly or pairs and rarely as short chains, and not spore forming.

The results of biochemical tests were adopted as a complementary characteristic of the initial diagnosis of $A$. hydrophila, where the results indicated that isolates belong to $A$. hydrophila, all isolates were positive result for oxidase test. A. hydrophila isolates are characterized by their ability to ferment glucose, it produces (alkaline) red color top and bottom (acidic) yellow color with gas formed but not $\mathrm{H}_{2} \mathrm{~S}$ on Triple Sugar Iron agar; it gives a positive result to catalase, indole, Simmon's citrate tests.

\section{Detection of virulence genes}

For the validation of $A$. hydrophila identification at molecular level, chosen strains were identified by $16 \mathrm{~S}$ rDNA PCR analysis. Amplified products were checked on $0.8 \%$ agarose gel, electrophoresis generated $685 \mathrm{bp}$ size fragment.

PCR amplification of DNA from $A$. hydrophila isolates using specific primers for AHCYTOEN (Act) genes resulted in the expected PCR products of $232 \mathrm{bp}$ sizes. Amplification result obtained through the present study shows the $130 \mathrm{bp}$ of haemolysin gene (ahh), which is reported earlier as a potent virulence gene of Aeromonas.

The band appearance of amplified virulent genes of samples was obtained through the $0.8 \%$ agarose gel electrophoresis and viewed in gel documentation system with $\mathrm{EtBr}$ stain and analyzed.

The pathogenicity and virulence characteristics of $A$. hydrophila are associated with presence of different exotoxins e.g., haemolysin, enterotoxins and cytotoxins and exoenzymes e.g., proteases and lipases [41].

Enterotoxin Act is the most cytotoxic virulence factor of and a core gene within $A$. hydrophila. An aerolysin related cytotoxic enterotoxin (Act) of Aeromonas hydrophila possesses multiple biological activities, which include its ability to lyse red blood cells, destroy tissue culture cell lines, evoke a fluid secretory response in ligated intestinal loop models, and induce lethality in mice. The role of Act in the virulence of the organism has been demonstrated [42]. 
Similar results were found by [43], where PCR amplification of DNA from pathogenic A. hydrophila isolates using specific primers for act genes resulted in the expected PCR products of $232 \mathrm{bp}$ sizes. Isolates have been classified as pathogenic due to presence of 232 bp gene in $0.8 \%$ agarose gel.

Screening of $232 \mathrm{bp}$ act gene has been reported to be the most effective way of diagnosis of Aeromonas virulence factors [44]. Previous clinical studies [45] reported that the expression of multiple biological activities, as in the case of the AHCYTOEN gene, is necessary for the expression of microbial pathogenicity. This cytolytic enterotoxin gene is considered as a characteristic virulence trait in Aeromonas [46].

Hemolysin (ahh1) has also been detected by [47] from the clinical isolates. The production of hemolytic cytotoxins has been regarded as strong evidence of pathogenic potential in Aeromonas [48].

Minimally processed vegetables have a physical structure which is susceptible to microbiological invasion. So, both microbiological and physiological activities could play a role in quality degradation. Results obtained in this study indicate the need for implementing food safety assurance programmes in the production chain of salads to improve their microbiological quality and need for food processors and consumers to adopt hygienic practices to minimize risks of transmission of foodborne pathogens through this kind of foods. This study revealed the potential hazard of ready-to-eat salads and emphasizes the need of surveillance studies for redressal of public health. Though microorganisms are part of the epiphytic flora of salads, their persistence and further proliferation contaminates the ready to eat foods which are dressed with fresh salad vegetables. There are an increasing number of outbreaks of human pathogens related to fresh produce. Thus, the growth of human pathogens on plants should be explored.

\section{References}

Aarestrup F M, Wegener H C and Collignon $P$ (2008) Resistance in bacteria of the food chain: epidemiology and control strategies. Expert Rev Anti Infect Ther. 6: $733-50$.

Bartz J A (1982) Infiltration of tomatoes immersed at different temperatures to different depths in suspensions of Erwinia carotovora sp. carotovora. Plant Dis. 66:302-306.

Berger C N, Sodha S V, Shaw R K, Griffin P $M$, Pink D, Hand $P$ and Frankel $G$ (2010) Fresh fruit and vegetables as vehicles for the transmission of human pathogens. Env Microbiol. 12: 2385-97.

Beuchat L R (1996) Pathogenic microorganisms associated with fresh produce. J Food Prot.59: 204-216.

Beuchat L R (2002) Ecological factors influencing survival and growth of human pathogens on raw fruits and vegetables. Microb Infect. 4: 413-23.

Brackett, R. E. 1993. Microbial quality, p. 134-137. In R. L. Shew- • et and S. E. Prussia (ed.), Postharvest handling. A systems approach. Academic Press, New York.

Buckley J T and Howard S P (1999) The cytotoxic enterotoxin of Aeromonas hydrophila is aerolysin. Infect Immun. 67: 466-467.

Burnett S Land Beuchat L R (2001) Human pathogens associated with raw produce and unpasteurized juices, and difficulties in decontamination. Journal of Industrial Microbiology and Biotechnology. 27:104-110.

Callister S M and Agger W A (1987) Enumeration and characterization of 
Aeromonas hydrophila and Aeromonas caviae isolated from grocery store produce. Appl Env Microbiol. 53: 24953.

Chopra A K, Houston C W, Genaux C T, Dixon J D and Kurosky A (1986) Evidence for production of an enterotoxin and cholera toxin crossreactive factor by Aeromonas hydrophila. J Clin Microbiol. 24: 66164.

Donkor, E.S., Lanyo, R., Kayang, B.B., Quaye, J., Edoh, D.A., 2010. Internalisation of microbes in vegetables: microbial load of Ghanaian vegetables and the relationship with different water sources of irrigation. Pakistan Journal of Biologial Sciences.13: 857-61.

Eckert J W and Ogawa J M (1988). The chemical control of postharvest diseases: deciduous fruits, berries, vegetables and root/tuber crops. Ann Rev Phytopathol. 26: 433-69.

European Commission Scientific Committee on Food (2002) Risk profile on the microbiological contamination of fruits and vegetables eaten raw. European Commission.ec.europa.eu/food/fs/sc/scf /out125_en.pdf.

FAO, 2009. How to feed the world in 2050. Food and Agriculture Organization (FAO), United Nations, Rome, Italy.

Fricker C R and Tompsett S (1989) Aeromonas spp. in foods: a significant cause of food poisoning. Int $J$ Food Microbiol. 9: 17-23.

Garcia-Gimeno R M, Sanchez-Pozo M D, Amaro-Lopez M A and Zurera-Cosano G (1996) Behaviour of Aeromonas hydrophila in vegetable salads stored under modified atmosphere at 4 and 15 degrees C. Food microbiol.

Gil Maria I (2015) Pre-and postharvest preventive measures and intervention strategies to control microbial food safety hazards of fresh leafy vegetables. Crit Rev Food Sci Nutr. 55: 453-68.

Gómez-López V M, Devlieghere F, Ragaert P and Debevere J (2007) Shelf-life extension of minimally processed carrots by gaseous chlorine dioxide. Int J Food Microbiol.116: 221-27.

Heuer H and Smalla K (2007) Manure and sulfadiazine synergistically increased bacterial antibiotic resistance in soil over at least two months. Env Microbiol.9: 657-66.

Ibenyassine K, Aitmhand R, Karamoko Y, Cohen N and Ennaji M M. (2006). Use of repetitive DNA sequences to determine the persistence of enteropathogenic Escherichia coli in vegetables and in soil grown in fields treated with contacted irrigation water. Letters in Applied Microbiology43: 528533.

Janda J M and Abbott S L (2010) The genus Aeromonas: taxonomy, pathogenicity, and infection. Clin Microbiol Rev. 23: 35-73.

Jeddi and Maryam Zare (2014) Microbial evaluation of fresh, minimallyprocessed vegetables and bagged sprouts from chain supermarkets. Journal of health, population, and nutrition. 32.3: 391.

Johnson D C, Enriquez C E, Pepper I, Davis, T L, Gerba C P and Rose J B (1997). Survival of Giardia, Cryptosporidium, poliovirus and Salmonella in marine waters. Water Science Technology35: 261- 268.

Keraita B, Drechsel P, Huibers F and Raschid-Sally L (2002) Wastewater use in informal irrigation in urban and periurban areas of Kumasi, Ghana. Urban agriculture magazine.

Khajanchi B K, Fadl A A, Borchardt M A, Berg RL., Horneman A J, Stemper M E, Joseph S W, Moyer N, Sha J and Chopra A K (2010) Distribution of 
virulence factors and molecular fingerprinting of Aeromonas species isolates from water and clinical samples: suggestive evidence of waterto-human transmission. Appl Env Microbiol. 76: 2313-25.

Lund B M (1992) Ecosystems in vegetable foods. J Appl Bacteriol. 73: 21.

McMahon M A S and Wilson I G (2001) The occurrence of enteric pathogens and Aeromonas species in organic vegetables. Int J Food Microbiol. 70: $155-62$.

Morgan D R, Johnson, H. L. Dupont, T. K. Satter White and L. V. Wood. Lack of Correlation between Known Virulence Properties of Aeromonas hydrophila and Enteropathogenicity for Humans. Infection and Immunity, Vol. 50, No. 1, 1988, 62-65.

Namdari H and Bottone EJ (1990) Cytotoxin and enterotoxin production as factors delineating enteropathogenicity of Aeromonas caviae. J Clin Microbiol. 28: 1796-98.

Newell D G, Koopmans M, Verhoef L, Duizer E, Aidara-Kane A, Sprong H, Opsteegh M, Langelaar M, Threfall J, Scheutz F and van der Giessen J (2010) Food-borne diseases - the challenges of 20 years ago still persist while new ones continue to emerge. Int $J$ Food Microbiol. 139: 3-15.

Palumbo S A, Call J, Huynh B and Fanelli J (1996) Survival and growth potential of Aeromonas hydrophila in reconditioned pork-processing-plant water. $J$ Food Prot. 59: 881-85.

Pao S, Davis C L and Parish M E (2001) Microscopic observation and processing validation of fruit sanitizing treatments for the enhanced microbiological safety of fresh orange juice. J Food Prot. 64: 310-314.

Parfitt J, Barthel $\mathrm{M}$ and Macnaughton $\mathrm{S}$ (2010) Food waste within food supply chains: quantification and potential for change to 2050. Philosophical Transactions of the Royal Society of London B: Biological Sciences. 365: 3065-81.

Park S, Szonyi B, Gautam R, Nightingale K, Anciso J and Ivanek R (2012) Risk factors for microbial contamination in fruits and vegetables at the preharvest level: a systematic review. J Food Prot. 75: 2055-81.

Qian Z (2012) A food-borne outbreak of Aeromonas hydrophila in a college, Xingyi City, Guizhou, China, 2012. Western Pacific Surveillance and Response Journal.3: 12-14.

Reis A A, Langkop C, Tauxe R V and Blake P A (1990) A multistate outbreak of Salmonella chester linked to imported Canataloupe. In: Program and abstracts of 30th Interscience Conference on Antimicrobial Agents and Chemotherapy (Atlanta). Washington, DC, Microbiol. Soc. Microbiol : 238 (Abstr).

Saad S, Iaria S T and Furlanetto S (1995) Motile Aeromonas spp in retail vegetables from Sao-Paulo, Brazil. Revista de Microbiologia. 26: 22-27.

Saddik M F, El-Sherbeeny M R and Bryan F L (1985) Microbiological profiles of Egyptian raw vegetables and salads. $J$ Food Prot. 48: 883-86.

Sarkar A, Saha M and Roy P (2013) Detection of 232bp Virulent Gene of Pathogenic Aeromonas hydrophila through PCR Based Technique: (A Rapid Molecular Diagnostic Approach). Asv Microbiol. 3: 83-87.

Sechi L A, Deriu A, Falchi M P, Fadda G and Zanetti S (2002) Distribution of virulence genes in Aeromonas spp. isolated from Sardinian waters and from patients with diarrhoea. $J$ Appl Microbiol. 92: 221-27.

Sharon E Y, Bashan Y, Okon and Y Henis 
(1981) Presymptomatic multiplication of Xanthomonas campestris pv. Vesicatoria on the surface of pepper leaves. Can J Bot.60:1041-1045.

Soriano J M, Rico H, Molto J C and Manes J (2000) Assessment of the microbiological quality and wash treatments of lettuce served in University restaurants. Int $J$ Food Microbiol. 58: 123-28.

Steinbruegge E G, Maxcy R B and Liewen M B (1988) Fate of Listeria monocytogenes on ready to serve lettuce. J Food Prot. 51: 596-99.

Walker S J and Brooks J (1993) Survey of the incidence of Aeromonas and Yersinia species in retail foods. Food control. 4: 34-40.

Wang G, Clark C G, Liu C, Pucknell C, Munro C K, Kruk T M, Caldeira R, Woodward D L and Rodgers F G (2003) Detection and characterization of the hemolysin genes in Aeromonas hydrophila and Aeromonas sobria by multiplex PCR. J Clin Microbiol. 41: 1048-54.

Yousr A H, Napis S, Ali R, Rusul G and Radu S (2007) Detection of aerolysin and hemolysin genes in Aeromonas spp. isolated from environmental and shellfish sources by polymerase chain reaction. ASEAN Food Journal. 14: 115-22.

Yu H B, Srinivasa Rao, Lee H C, Vilches S, Merino S, Tomas $\mathrm{J} \mathrm{M}$ and Leung $\mathrm{K} \mathrm{Y}$ (2005) A Type III secretion system is required for Aeromonas hydrophila $\mathrm{AH}-$ 1 pathogenesis. Infect Immun.72: 124856.

Zagory D (1999) Effects of post-processing handling and packaging on microbial populations. Postharvest Biol. Technol. 15: 313-21.

\section{How to cite this article:}

Kamalpreet Kaur, Param Pal Sahota, Mandeep Singh Hunjan, Bhavish Sood, Manmeet Kaur and Jaspreet Kaur. 2017. Occurrence and Virulence Characterization of Aeromonas hydrophila in Salad Vegetables from Punjab. Int.J.Curr.Microbiol.App.Sci. 6(11): 693-707. doi: https://doi.org/10.20546/ijcmas.2017.611.082 